Table 1 Facet Biotech pipeline

\begin{tabular}{lllll} 
Drug & Description & Indication & Status & Partner \\
\hline Daclizumab & $\begin{array}{l}\text { Humanized monoclonal antibody that MS } \\
\text { binds alpha subunit of IL-2 receptor }\end{array}$ & Phase 2 & Biogen Idec \\
\hline Volociximab & $\begin{array}{l}\text { Chimeric monoclonal antibody that } \\
\text { binds } \alpha_{5} \beta_{1} \text { integrin }\end{array}$ & Solid tumors & Phase 2 & Biogen Idec \\
\hline Elotuzumab & $\begin{array}{l}\text { Humanized monoclonal antibody that Multiple myeloma } \\
\text { binds CS1 glycoprotein }\end{array}$ & Phase 1 & $\begin{array}{l}\text { Bristol-Myers Squibb } \\
\text { (BMS) }\end{array}$ \\
\hline PDL192 & $\begin{array}{l}\text { Humanized monoclonal antibody } \\
\text { that binds TweakR (tumor necrosis } \\
\text { factor-like weak inducer of apoptosis } \\
\text { receptor) }\end{array}$ & Phase 1 & - \\
\hline PDL241 & $\begin{array}{l}\text { Humanized monoclonal antibody that Multiple myeloma } \\
\text { binds CS1 glycoprotein }\end{array}$ & Preclinical & BMSa $^{2}$ & \\
\hline
\end{tabular}

aBMS retains an option on this program.

York. "The real hurdle to drug discovery in MS has been good efficacy coupled with a good safety profile."

"There's very little doubt, based on its use in other indications, that it will have side effects," says Bret Holley, biotech analyst at Oppenheimer \& Co. in New York. "It's very tough to see how it differentiates against other MS therapies that are on the market or in the pipeline." As clinical data are limited, the real test will be its effect on relapse rate and its long-term safety profile in a large population. But so far, Holley says, Zenapax appears to offer efficacy intermediate between that of the older, so-called ABCR drugs (Avonex, Betaseron, Copaxone and Rebif) and newer, more potent therapies, such as Tysabri (natalizumab), Gilenia (fingolimod/FTY720), which the FDA has under priority review, and cladribine, to which the FDA gave an initial rebuff last year.

Given the drug's relatively mild immuno- suppressive effects, it could find a niche as part of a combination therapy. "Daclizumab has been used with lots of other immunosuppressive agents, so it might be of value there," says Waldmann. The recent phase 2 study did not definitively show that the combination was responsible for the benefit seen, as the trial did not include a Zenapax-only arm. Moreover, some patients who developed neutralizing antibodies against interferon- $\beta$ therapy still derived benefit. “There's really been essentially no large trial that has shown that combination therapy was better than each of the components individually," says Jeffrey Cohen, of the Cleveland Clinic, in Cleveland. Even so, Cohen also predicts that drug could have a future- - even if it's a modest one. "We still need additional therapeutic options in MS," he says. "Almost any additional option in our repertoire is good."

Cormac Sheridan Dublin

\section{IN their words}

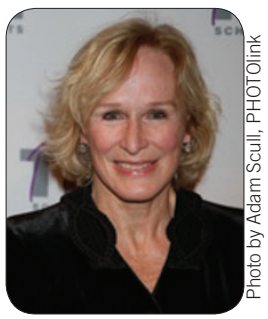

Illumina reaches Hollywood

"The environment to launch new product...is going to be tougher, the pricing is going to be tougher, the probability (of drug approvals) is probably going to be more challenging." Biogen Idec's James $C$. Mullen, who is leaving the firm in June, paints a less-than-rosy future for biotechs after healthcare reform. (The Boston Globe, 31 March 2010)
San Diego-based Illumina genome of actress Glenn Close, whose family has a history of mental illness. She took advantage of the $\$ 48,000$ service in the hope that it would help destigmatize the disease and aid efforts to find a cure for these ailments. Close's husband is a biotech entrepreneur. has sequenced the
"Right now your family history may be your best bet and it doesn't cost anything," Francis Collins, director of the US National Institutes of Health and leader of the Human Genome Project, downplays the impact of gene-based tests such as those offered by Navigenics, 23andMe and DecodeMe. (Reuters, 31 March 2010)

"I personally believe that Becky McClain is really the canary in the coal mine." Jeremy Gruber, from the Council of Responsible Genetics, on the recent $\$ 1.4$ million in compensation awarded to a former Pfizer scientist who claimed a genetically engineered virus had caused her paralyzing illness, stresses that safety regulations have not kept up with the pace of research. (New York Times, 2 April 2010)

"Merck is now a bigger beast to feed." Merck's Margaret Beer urges biotechs gathered at a recent conference in London to approach the newly expanded company, as it is still actively searching for opportunities. (PharmaTimes, 29 March 2010)
IN brief

\section{Ariad's NF-кB blow}

The US Court of Appeals for the Federal Curcuit in March ruled for Eli Lilly in Indianapolis, Indiana, and against Ariad Pharmaceuticals, affirming an earlier decision by a three-judge panel and dealing a possible death blow to Ariad's broad claims on the nuclear factor $\mathrm{\kappa B}$ (NF-KB) pathway (Nat. Biotechnol. 27, 494, 2009). A 2006 jury ruling that Lilly's Evista (raloxifene) and Xigris (activated protein C) infringed Cambridge, Massachusettsbased Ariad's NF-KB patent alarmed much of the drug development world, stoking fears that broad patent claims on biological pathways would stifle drug development. The March opinion again invalidated Ariad's claims and affirmed that patents must meet a written description requirement separate from an enablement requirement - an issue that has divided the appeals court since a 1997 ruling established written description, dubbed the Lilly doctrine (Nat. Biotechnol. 16, 87, 1998). Ariad is considering petitioning for Supreme Court review. But the Supreme Court has "bigger fish to fry with patentable subject matter right now," says University of Michigan law professor Rebecca Eisenberg, alluding to Association for Molecular Pathology v. US Patent and Trademark Office (the Myriad Genetics gene patenting case, seemingly destined for Supreme Court review), and Prometheus v. Mayo, another dispute over the patentability of 'natural processes'. Ariad also lost an NF- $\mathrm{KB}$ patent infringement case against Amgen, of Thousand Oaks, California, and the US Patent and Trademark Office invalidated most of Ariad's patent claims in a separate review (Ariad has appealed), suggesting the NF- $\mathrm{KB}$ patent has little life left.

Ken Garber

\section{Orphan drug workshops}

In an effort to increase the number of drugs available to treat rare diseases and to help make the US Food and Drug Administration (FDA) more approachable, the FDA is hosting a series of workshops to encourage regulatory submissions for orphan drug designation for drugs aimed at treating rare diseases. The agency's Office of Orphan Products Development (OOPD) is holding these events to help academics, biotech companies and those unfamiliar with the process complete the best application possible. The first workshop, held in February at the Claremont, California-based Keck Graduate Institute, resulted in 14 submissions from the 29 potential sponsors who attended. Timothy Coté, director of the OOPD, explains that the workshops are "a way to demystify the process," which is sometimes deemed to be daunting. "Sponsors approach the FDA with considerable fear and loathing. And that's not a good thing," he says. Though an orphan drug status does not ensure a drug will be approved for sale, the designation typically helps attract investor interest and provides other benefits, such as seven years of market exclusivity and tax credits. Coté hopes that these workshops will be the "beginning of a more candid relationship" between the FDA and potential sponsors and that they will increase the chances of rare-disease therapies reaching the clinic.

Kirsten Dorans 